\title{
Serum apolipoproteins AI and B and lipoproteins in middle aged men with and without previous myocardial infarction
}

\author{
P N DURRINGTON, L HUNT, M ISHOLA, J KANE, W P STEPHENS \\ From the University of Manchester Department of Medicine and Medical Computational Group, Manchester \\ Royal Infirmary, and Department of Chemical Pathology, University Hospital of South Manchester, \\ Manchester
}

SUMMARY The serum high density lipoprotein (HDL) subfractions, $\mathrm{HDL}_{2}$ and $\mathrm{HDL}_{3}$, and serum apolipoprotein $\mathrm{AI}$ and $\mathrm{B}$ (apo $\mathrm{AI}$ and $\mathrm{B}$ ) were evaluated as potential indicators of the risk of ischaemic heart disease in men aged $<60$ years who had previously had a myocardial infarction and in controls with a similar socioeconomic background who had no history of myocardial ischaemia. Discriminant analysis confirmed that the combination of serum cholesterol, triglycerides, and total HDL cholesterol distinguished poorly between patients and controls. The best single discriminating variable was apo B. Stepwise discriminant analysis showed that this discrimination could be improved to a small extent by combining apo B with apo AI and parental history, but nothing was gained by measurement of serum cholesterol triglycerides, very low density lipoprotein cholesterol, low density lipoprotein cholesterol, $\mathrm{HDL}$ cholesterol, $\mathrm{HDL}_{2}$ or $\mathrm{HDL}_{3}$ cholesterol. Significantly more patients than controls with type IV hyperlipoproteinaemia had raised concentrations of serum apolipoprotein $\mathrm{B}$, but the frequency of raised apolipoprotein $B$ concentrations was no greater in patients with type IV hyperlipoproteinaemia than in those with normal serum lipids.

The value of apo B as an indicator of cardiovascular risk should be assessed in prospective studies.

Serum cholesterol has been widely accepted as a risk factor for ischaemic heart disease. The median serum cholesterol concentration for different populations correlates closely with the prevalence of ischaemic heart disease. ${ }^{1}$ Apart from the exceptional patient with monogenic familial hypercholesterolaemia, ${ }^{2} 3$ however, serum cholesterol does not discriminate well between individuals in whom ischaemic heart disease develops at an early age and those in whom it does not. In the Framingham study and in all subsequent similar population studies there was a considerable overlap between the distribution of the serum cholesterol concentration of men in whom ischaemic heart disease developed and of those in whom it did not. ${ }^{45}$ It

Requests for reprints to $\operatorname{Dr} P$ N Durrington, Department of Medicine, Manchester Royal Infirmary, Manchester M13 9WL.

Accepted for publication 9 June 1986 has been calculated that more than three quarters of men in whom ischaemic heart disease develops cannot be identified by their serum cholesterol concentration and that of those whose serum cholesterol exceeds $300 \mathrm{mg} / \mathrm{dl}(7.7 \mathrm{mmol} / \mathrm{l})$ less than one tenth will die prematurely of ischaemic heart disease. ${ }^{6}$ Serum triglycerides do not discriminate better than total serum cholesterol, ${ }^{7}$ and serum low density lipoprotein (LDL) cholesterol and serum high density lipoprotein (HDL) cholesterol provide only marginally better discrimination. ${ }^{8}$

This lack of ability accurately to distinguish individuals at risk poses great difficulties in planning a strategy for the prevention of ischaemic heart disease. Ideally, preventive measures should be directed at individuals most likely to benefit rather than whole nations ${ }^{910}$ or large numbers of people selected by arbitrary use of imprecise discriminants such as serum cholesterol. ${ }^{11}$

Recently, new risk factors for ischaemic heart dis- 
ease have been proposed as being potentially more discriminating. These include the $\mathrm{HDL}_{2}$ and $\mathrm{HDL}_{3}$ subfractions of serum HDL, ${ }^{12} 13$ apolipoprotein AI (apo AI) (the major apolipoprotein of HDL), ${ }^{1415}$ and apolipoprotein B (apo B) (the major apolipoprotein of LDL). ${ }^{1416-18}$ We have compared the value of these discriminants in identifying men known to have ischaemic heart disease at an early age.

\section{Patients and methods}

\section{PATIENTS AND CONTROLS}

Male patients aged $<60$ years were sought from the records of the coronary care unit of the Manchester Royal Infirmary. The hospital notes of such men were examined and surviving men with definite evidence of acute myocardial infarction ${ }^{19}$ more than six months previously, who were not receiving treatment with $\beta$ adrenoreceptor blocking drugs or thiazide diuretics, were invited to participate in the study, which had the approval of the hospital ethics committee. Of the men asked to take part, $79 \%$ of those still living did so. They were studied (SD) a mean of $18.8(8.6)$ months after their myocardial infarction. Obese patients had generally been advised to lose weight after their myocardial infarction, but no other dietary advice had been given. The average decrease in body weight between that reported before myocardial infarction and that determined in this investigation was only $1.2 \mathrm{~kg}$.

The controls were volunteers from two local factories. They had no personal history of ischaemic heart disease, peripheral arterial disease, or cerebrovascular disease as assessed during an interview by one of us (PND) using the Rose questionnaire ${ }^{20}$ and supplementary questions. Both patients and controls were excluded from the study if they were known to have any chronic medical condition such as diabetes mellitus or to be on any drug or dietary treatment known to affect serum lipids. We used a standard questionnaire to obtain information about smoking habits, alcohol intake, family history of myocardial infarction before the age of 60 in the father or before the age of 70 in the mother, occupation (before heart attack in case of patients), and exercise. Patients were also asked about changes in weight, smoking, and occupation since their heart attack. Height, weight, and blood pressure after lying for $5 \mathrm{~min}$ were measured in all men and a blood sample was taken between 9.00 and $11.00 \mathrm{am}$. Both patients and controls had fasted from $10.00 \mathrm{pm}$ the previous night.

At the completion of the study 130 men (48 patients and 82 controls) had been examined. One patient and one control were later excluded because their serum contained floating $\beta$ lipoprotein. ${ }^{21}$

Patients and controls were compared by Student's $t$ test for variables with a gaussian distribution (Kolmogorov-Smirnov test) ${ }^{22}$ after log transformation, if necessary, as in the case of serum triglycerides and of serum very low density lipoprotein (VLDL) cholesterol. Variables such as alcohol intake which could not be made gaussian by log transformation were compared by the MannWhitney U test. ${ }^{22}$ Variables which could appropriately be regarded as raised or normal or all or none were in some cases compared in the two populations by the $\chi^{2}$ test. Stepwise discriminant analysis was performed according to the Statistical Package for the Social Sciences. ${ }^{23}$

\section{LABORATORY METHODS}

Lipid concentrations in whole serum and isolated lipoproteins were determined enzymatically, cholesterol by means of a reagent supplied by Diamed A G (Murten, Switzerland), and triglycerides by the GPO-PAP method (Boehringer Mannheim). Very low density lipoproteins were isolated by tube slicing (Spinco Tube Slicer, Beckman Instruments Palo Alto, Ca, USA) as the supernatant after ultracentrifugation ${ }^{24}$ of $5 \mathrm{ml}$ of plasma overlayered with saline (density $1.006 \mathrm{~g} / \mathrm{ml}$ ) at $100000 \times g$ for 24 $\mathrm{h}$ (Superspeed 65 ultracentrifuge with $18 \times 6.5 \mathrm{ml}$ rotor, MSE Ltd, Crawley, Sussex). HDL and $\mathrm{HDL}_{3}$ were isolated as the infranatant from $3 \mathrm{ml}$ and $2 \mathrm{ml}$ of plasma converted to densities of 1.063 and $1.125 \mathrm{~g} / \mathrm{ml}$ respectively ${ }^{24}$ after ultracentrifugation for 48 hours. HDL was also isolated from serum by precipitation of other lipoproteins with sodium phosphotungstate and magnesium chloride. ${ }^{25}$ The concentration of cholesterol in $\mathrm{HDL}_{2}$ was determined by subtraction of $\mathrm{HDL}_{3}$ cholesterol determined by ultracentrifugation ( $\mathrm{HDL}_{3 \mathrm{Uc}}$ ) from total high density lipoprotein cholesterol determined both by ultracentrifugation (HDLuc) and by phosphotungstate precipitation (HDLPT). Total $\mathrm{HDL}, \mathrm{HDL}_{2}$, and $\mathrm{HDL}_{3}$ cholesterol concentrations were also measured by a precipitation method involving heparin and manganese chloride and dextran sulphate ${ }^{26}$ with modification of the cholesterol reagent by the addition of edetic acid. ${ }^{27}$ In the statistical analysis results obtained by this method proved to be inferior in the identification of men with previous myocardial infarction and are not, therefore, presented here. The concentration of low density lipoprotein (LDL) cholesterol was determined (a) by subtraction of the sum of HDLuc cholesterol and VLDL cholesterol from total serum cholesterol and (b) by calculation from total serum triglycerides and cholesterol and HDLuc cholesterol or (c) HDLPT cholesterol. ${ }^{28}$ Serum apo B and apo AI were deter- 

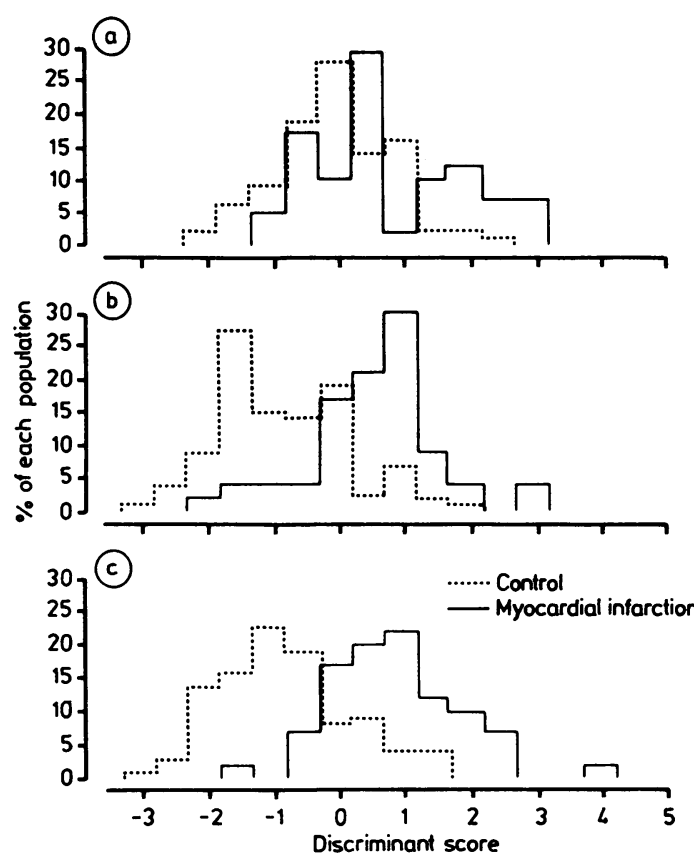

Figure Frequency distribution of the scores in controls and men with previous myocardial infarction obtained by discriminant analysis using as variables (a) conventional risk factors (total serum cholesterol, serum triglycerides, serum $H D L_{\mathrm{PT}}$ cholesterol, and parental history), (b) apolipoprotein $B$ alone, and (c) variables selected by stepwise discriminant analysis (table 3) (apolipoprotein $B$, apolipoprotein $A I$, and parental history).

mined by immunoelectrophoresis ${ }^{29} 30$ with antisera supplied by Immuno Ltd (Dunton Green, Kent).

\section{Results}

\section{CHARACTERISTICS OF PATIENTS AND}

CONTROLS

Patients and controls differed little in their age and body mass (table 1 ). They were closely matched for their socioeconomic background as judged by the Registrar General's coding (controls were $19 \%$ class I, $24 \%$ II, $28 \%$ III, $12 \%$ IV, and $17 \%$ V and patients were $17 \%$ I, $27 \%$ II, $27 \%$ III, $12 \%$ IV, and $17 \% \mathrm{~V})$. Both groups were also similar with respect to systolic and diastolic blood pressures, the proportion who were cigarette smokers, who were teetotal, and who regularly exercised. More alcohol was drunk by the control group, but this did not achieve statistical significance. A significantly higher proportion of patients with previous myocardial infarction than of controls reported that one or both parents had suffered a premature heart attack.
SERUM LIPIDS, LIPOPROTEINS, AND

APOLIPOPROTEINS IN PATIENTS AND

CONTROLS

Although the mean serum concentrations of cholesterol, LDL cholesterol, and triglycerides were higher in the men with previous myocardial infarction these differences were not statistically significant. Serum apolipoprotein B concentrations were, however, clearly higher in the patients than in the controls (table 2). Serum VLDL cholesterol concentration was also significantly raised in patients. All serum LDL cholesterol methods gave very similar results. For patients and controls combined $(n=130$, mean $(S D))$ serum LDL cholesterol was $4.46(1.33) \mathrm{mmol} / \mathrm{l}$ by subtraction of HDLuc and VLDL cholesterol from total serum cholesterol. By the Friedewald calculation ${ }^{28}$ serum LDL cholesterol was $4.42(1.36) \mathrm{mmol} / \mathrm{l}$ when HDLuc was used and it was $4.42(1.37) \mathrm{mmol} / \mathrm{l}$ when HDLPT was used. Unless otherwise stated the former entirely ultracentrifugation method of determining LDL cholesterol with direct measurement of HDL and VLDL cholesterol is reported.

On average serum HDL cholesterol concentrations were higher in the controls, with the difference achieving statistical significance when the phosphotungstate method was used. Serum apo AI was also significantly lower in men with previous myocardial infarction. The difference in serum HDL cholesterol between patients and controls appeared to be largely due to variations in the concentration of cholesterol in the $\mathrm{HDL}_{2}$ subfraction.

\section{DISCRIMINANT ANALYSIS}

\section{Discriminating variables}

Stepwise discriminant analyses were performed to determine which variables were most important in differentiating between men with previous myo-

Table 1 Characteristics (mean (SD)) of the 47 men with a previous myocardial infarction and 81 disease free controls at the time of study

\begin{tabular}{lcl}
\hline & Control & $\begin{array}{l}\text { Previous myocardial } \\
\text { infarction }\end{array}$ \\
\hline Age (yr) & $50(7)$ & $52(7)$ \\
Body weight $(\mathbf{k g})$ & $77(10)$ & $76(8)$ \\
Height (m) & $1 \cdot 74(0.06)$ & $1 \cdot 74(0 \cdot 07)$ \\
Quetelet's index & $25 \cdot 6(2 \cdot 8)$ & $25 \cdot 3(3 \cdot 0)$ \\
Systolic BP (mm Hg) & $133(19)$ & $130(18)$ \\
Diastolic BP (mm Hg) & $82(12)$ & $78(10)$ \\
Alcohol intake (g/wk) & $98(0-810) \dagger$ & $69(0-653) \dagger$ \\
Teetotal (\%) & 12 & 13 \\
Cigarette smokers (\%) & 28 & 26 \\
Considerable exercise $(\%)$ & 25 & 23 \\
Parental history (\%) & 11 & $32 \ddagger$ \\
\hline
\end{tabular}

^Control values from Winacour PH, Durrington PN, Ishola M, Anderson DC. Lipoprotein abnormalities in insulin-dependent diabetes mellitus. Lancet 1986;i:1176-8.

†Median (range). $\ddagger \chi^{2}=6.29 ; p=0.01$. BP, blood pressure. 
Table 2 Concentrations (mean (SD) or geometric mean ( $+1 S D,-1 S D)$ ) of serum lipids, lipoproteins, and apolipoproteins $A I$ and $B$ in 47 men with previous myocardial infarction and 81 controls

\begin{tabular}{|c|c|c|}
\hline Variable & Control & $\begin{array}{l}\text { Previous myocardial } \\
\text { infarction }\end{array}$ \\
\hline 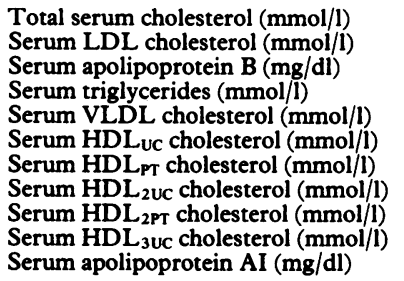 & $\begin{array}{l}6.34(1.14) \\
4.31(1.21) \\
137(29) \\
1.30(+0.90,-0.53) \\
0.44(+0.39,-0.21) \\
1.36(0.32) \\
1.36(0.33) \\
0.73(0.32) \\
0.73(0.35) \\
0.63(0.20) \\
108(15)\end{array}$ & $\begin{array}{l}6.51(1.59) \\
4.53(1.54) \\
177(30)^{\star \star \star} \\
1.44(+1.18,-0.65) \\
0.62(+0.59,-0.30)^{\star \star} \\
1.24(0.37) \\
1.20(0.33)^{\star} \\
0.67(0.33) \\
0.63(0.35) \\
0.57(0.24) \\
97(17)^{\star \star \star}\end{array}$ \\
\hline
\end{tabular}

${ }^{\star} \mathrm{p}<0.02{ }^{\star \star} \mathrm{p}<0.005 ;{ }^{\star \star \star} \mathrm{p}<0.001$.

UC, ultracentrifugation; PT, phosphotungstate.

cardial infarction and those without. These variables were used to compute scores for the likelihood of individuals belonging to the patient or control groups. Various combinations of variables were assessed, the fullest of which included parental history, total serum cholesterol, log serum triglycerides, log VLDL cholesterol, LDL cholesterol by subtraction of $H_{D L}$ and $V_{U L D} L_{U c}$ from total serum cholesterol, LDL cholesterol by the Friedewald formula, HDL $\mathrm{LC}_{\mathrm{UC}}$ and $\mathrm{HDL}_{\mathrm{PT}}, \mathrm{HDL}_{2 \mathrm{CC}}$ cholesterol and $\mathrm{HDL}_{2 \mathrm{PT}}$ cholesterol, $\mathrm{HDL}_{3} \mathrm{Uc}$ cholesterol, serum apo AI, and serum apo B.

In every analysis serum apo $B$ was always the most discriminating variable (as judged by discriminant function coefficients) and had to be included first to provide the best model (see table 3). This was true irrespective of the serum cholesterol concentration. Other variables that significantly improved discrimination were serum apo AI concentration and the presence of a parental history of premature heart attack. The inclusion of other lipoprotein or lipid concentrations did not improve the discrimination provided by apolipoprotein B, apolipoprotein AI, and parental history. Only in men with serum cholesterol $<6.4 \mathrm{mmol} / 1(250 \mathrm{mg} / \mathrm{dl})$ was serum HDL $_{u c}$ cholesterol more discriminating than apo AI. In this group of men the difference in HDL cholesterol concentrations between controls and patients achieved statistical significance.

DISCRIMINATING ABILITY OF VARIABLES

When serum apolipoproteins $B$ and $A I$ and parental history were used $81 \%$ of controls and $81 \%$ of myocardial infarction patients were correctly identified by a discriminant score midway between the mean discriminant scores for the two populations (equal prior probability). The importance of apo $B$ in this model was well demonstrated because when apo $B$ was used as the sole discriminating variable $73 \%$ of controls and $83 \%$ of men with previous myocardial infarction were correctly identified. On the other hand, discriminant scores computed by the best model provided by conventional risk factors (serum cholesterol, log serum triglycerides, serum HDL $_{\text {PT }}$ cholesterol, and parental history) correctly identified only $65 \%$ of controls and $56 \%$ of the patients. The figure shows the frequency distribution of the discriminant scores provided by these different groups of variables.

\section{LACK OF INFLUENCE OF PARENTAL HISTORY \\ ON THE CONCENTRATION OF SERUM APOLIPOPROTEINS AI OR B}

In the present study parental history of premature myocardial infarction was not associated with lower serum apo AI concentrations or higher serum apo B

Table 3 Results of a stepwise discriminant analysis which included as variables parental history, total serum cholesterol, log serum triglycerides, log VLDL cholesterol, $L D L$ cholesterol, $H D L_{\mathrm{Uc}}$ and $H D L_{\mathrm{PT}}$ cholesterol, $H D L_{2 \mathrm{Uc}}$ and $H D L_{2 \mathrm{PT}}$ cholesterol, $H D L_{3}$ uc cholesterol, and apolipoproteins $A I$ and $B$

\begin{tabular}{|c|c|c|c|}
\hline \multirow[b]{2}{*}{ Order of inclusion } & \multirow[b]{2}{*}{ All patients and controls $\dagger$} & \multicolumn{2}{|l|}{ Variables contributing significantly ${ }^{\star}$} \\
\hline & & Serum cholesterol $\leqslant 6.4 \mathrm{mmol} / 1 \ddagger$ & Serum cholesterol $>6.4 \mathrm{mmol} / \mathrm{l} \S$ \\
\hline $\begin{array}{l}1 \\
2 \\
3\end{array}$ & $\begin{array}{l}\text { Apolipoprotein B }(0.89) \\
\text { Apolipoprotein AI }(0.35) \\
\text { Parental history }(0.32)\end{array}$ & $\begin{array}{l}\text { Apolipoprotein B (0.95) } \\
\text { HDL Uc cholesterol }(0.49)\end{array}$ & $\begin{array}{l}\text { Apolipoprotein B }(0.91) \\
\text { Apolipoprotein AI }(0.61)\end{array}$ \\
\hline
\end{tabular}

The most discriminating order of inclusion and the variables contributing to the discrimination at ${ }^{\star} p<0.05$ are shown. Numerals in parentheses are the standardised canonical discriminant function coefficients. Complete data available in $n=120 \dagger, n=58, \ddagger$ and $n=62 . \S$ 
Table 4 Concentrations of serum apolipoproteins AI and B (mean (SD)) in men with previous myocardial infarctions and their controls with and without a history of premature myocardial infarction in either or both parents (mother aged $<70$ years; father aged <60 years)

\begin{tabular}{lcc}
\hline & Parental history & None \\
\hline $\begin{array}{l}\text { Serum apolipoprotein AI (mg/dl): } \\
\text { Control }\end{array}$ & $110(16)(\mathrm{n}=9)$ & $107(15)(\mathrm{n}=70)$ \\
Previous myocardial infarction & $96(12)(\mathrm{n}=13)$ & $99(19)(\mathbf{n}=28)$ \\
Serum apolipoprotein B (mg/dl): & $135(24)(\mathrm{n}=9)$ & $137(30)(\mathrm{n}=72)$ \\
$\quad$ Control & $180(38)(\mathrm{n}=13)$ & $179(23)(\mathrm{n}=28)$ \\
\hline
\end{tabular}

concentrations in either men with previous myocardial infarction or their controls (table 4).

FREQUENCY OF RAISED SERUM

APOLIPOPROTEIN B IN PATIENTS AND

CONTROLS WITH TYPE IV

HY PERLI POPROTEINAEMIA

Thirteen patients and 17 controls had type IV hyperlipoproteinaemia (serum cholesterol $<7 \cdot 7$ $\mathrm{mmol} / \mathrm{l}$ and serum triglycerides $>1.8 \mathrm{mmol} / \mathrm{l}$ ) (table 5). A significantly greater proportion of the patients had raised concentrations of serum apo $B(>155$ $\mathrm{mg} / \mathrm{dl}$, the concentration midway between the means of men with previous myocardial infarction and of controls) than did controls with type IV hyperlipoproteinaemia. Serum concentrations of apo B > $155 \mathrm{mg} / \mathrm{dl}$ were found in $30 \%$ of controls with "normal" serum lipids (cholesterol $<7.7$ and triglycerides $<1.8 \mathrm{mmol} / \mathrm{l}$ ) and $29 \%$ of controls with type IV hyperlipoproteinaemia. There was no significant difference between the frequency of raised serum apo $B$ concentration in patients with "normal" serum lipids concentrations and those with type IV hyperlipoproteinaemia.

\section{Discussion}

In 1974 Fredrickson, commenting about apo B, said that "its resistance to characterisation, its seeming essentiality for glyceride transport, and perhaps the

Table 5 Percentage of patients and controls with raised serum apolipoprotein $B$ concentrations with normal lipid concentrations or type IV hyperlipoproteinaemia

\begin{tabular}{ll}
\hline & $\begin{array}{l}\text { Serum apolipoprotein } \\
B>155 \mathrm{~g} / \mathrm{dl}\end{array}$ \\
\hline Normal lipids: & \\
Previous myocardial infarction $(\mathrm{n}=25)$ & $92 \%$ \\
$\begin{array}{l}\text { Controls }(\mathrm{n}=53) \\
\text { Type IV hyperlipoproteinaemia: }\end{array}$ & $\begin{array}{l}30 \% \\
\text { Previous myocardial infarction }(\mathrm{n}=13)\end{array}$ \\
$\begin{array}{l}77^{\circ} \\
\text { Controls }(\mathrm{n}=17)\end{array}$ & $29 \%$ \\
\hline$\chi^{2}$ test $={ }^{\star} \mathrm{p}=0.026 ;{ }^{\star} \mathrm{p}<0.0005$. &
\end{tabular}

added suspicion that it has something to do with atherogenesis, have all transformed apo B into one of the central mysteries of lipoprotein physiology." 31 Despite the wealth of experimental evidence that might support such a view there have been remarkably few attempts to provide epidemiological evidence for it. Perhaps this is because much attention has been focused on HDL cholesterol in recent years ${ }^{32}$ and because of the disappointing results with LDL cholesterol as a risk factor. ${ }^{3-5}$ There is, however, considerable individual variation in the serum concentration of LDL apo B that is independent of that of LDL cholesterol. ${ }^{1617}$ In a study of similar design to the present one Avogaro and coworkers found that the ratio of apo AI to apo B appeared to discriminate between men with ischaemic heart disease and controls better than serum cholesterol, triglycerides, and HDL cholesterol. ${ }^{17}$ They did not determine HDL subfraction concentrations, which some studies have suggested may be more discriminating, and did not use discriminant analysis to test their conclusions. Later Sniderman et al in a study of patients with and without important coronary atheroma suggested that apo $B$ might be a valuable risk factor, ${ }^{18}$ but this was in comparison with serum cholesterol, triglycerides, and LDL cholesterol; HDL, HDL subfractions, and apo AI were not compared, and again the conclusion was not tested by discriminant analysis. The present study although small is therefore of great importance because apo B measured by a simple electrophoretic technique contributed more to the identification of men with ischaemic heart disease than all these other risk factors. Furthermore, apo B, apo AI, and a knowledge of parental history provided a discriminant score that could not be improved upon by addition of HDL subfractions or any of the other lipoproteins or lipids measured. The rate of detection provided by conventional lipid screening tests (serum cholesterol, triglycerides, and HDL cholesterol) was poor by comparison, indicating that a screening policy for individuals at risk of premature ischaemic heart disease is likely to be unsound unless apo B is included.

Sniderman et al reported an increase in serum apo 
$B$ concentrations in a third of the children of parents with raised serum apo B concentrations that had been discovered when the parents presented with ischaemic heart disease. ${ }^{34}$ Their observation is not necessarily incompatible with our finding that a parental history of premature myocardial infarction did not influence the concentration of serum apo B. Our subjects were not selected because of their lineage. A single gene is unlikely to determine both the risk of ischaemic heart disease and the concentration of serum apo B. It is more probable that a gene or genes participating in the development of high serum apo B concentrations may cause accelerated coronary atherogenesis when combined with other genes or familial characteristics that increase the susceptibility to atheroma. An individual with premature myocardial infarction and raised apo B concentration may have inherited this combination of factors from one parent, but, perhaps even more commonly, may do so in part from both parents. Neither parent may have a history of premature ischaemic heart disease because both influences are not operating in them.

Environmental, particularly nutritional, effects in our study may also have been more influential than in the offspring studied by Sniderman et al. ${ }^{34}$ They were on average 17 years old and had much lower serum and LDL cholesterol concentrations than the men in our study. Genetic influences on serum apo $B$ may be more discernible in young people, whereas in older people nutritional and other environmental effects may predominate. The diet of men in the North West of England may also be different from that in North America. Certainly the quantity and type of dietary fat can considerably alter serum apo B concentrations. ${ }^{35} 36$ Nevertheless, genetic differences in dietary response are the simplest explanation for the difference in serum apo $B$ concentrations between the patients and controls in our study; because they are so similar in all other respects major dietary differences are unlikely. A genetic effect on serum apo B concentrations is also suggested by their possible association with a restrictive site polymorphism in the apo $B$ gene. ${ }^{37}$

There has been much debate about whether serum triglycerides are a risk factor for ischaemic heart disease. ${ }^{7}$ We have previously reported unexpectedly high levels of LDL apo $B$ in some patients with type IV hyperlipoproteinaemia (and by definition normal LDL cholesterol). ${ }^{16}$ The present study supports the view proposed by Sniderman et al that it is this type of patient with type IV hyperlipoproteinaemia who is at risk of ischaemic heart disease. ${ }^{33}$ Our finding that the frequency of raised concentrations of serum apo $B$ was no greater in men with hypertriglyceridaemia than in those with normal serum lipids when those with and those without ischaemic heart disease were analysed separately would also explain why serum triglycerides are such a poor risk factor. The suggestion from our earlier work that increased serum apo $B$ might be more common in type IV hyperlipoproteinaemia ${ }^{16}$ probably arose because some patients with type IV had been discovered because of ischaemic heart disease that was absent in the controls, and also because the hypertriglyceridaemia was more extreme than in the present investigation.

The method that we used in this study measured total serum apo $\mathrm{B}$ concentration. ${ }^{1629}$ Another method that uses radial immunodiffusion may more closely reflect serum LDL apo B concentration. ${ }^{18}$ It is, however, unlikely that this would be a major advantage since VLDL, the other serum lipoprotein containing apo $\mathrm{B}$ in the fasting state, makes only a small contribution to the total apo $B$ in serum even at VLDL concentrations exceeding any in the present study. ${ }^{16}$

The present study suggests that apo B may identify men at risk of premature heart attacks better than currently available risk factors. A finer definition of high risk patients would not only allow the more economic use of health resources, but would also allow patients to be given more definite advice and would enable drugs to be used when their benefit could more clearly be seen to outweight their possible ill effects. In developing a rational approach to the prevention of ischaemic heart disease the further evaluation of apo $B$ as a predictive factor in prospective studies will be important if preventive measures are to be aimed at the individual rather than the whole population.

We thank Dr H M MacAdoo and Sisters P Bates and $\mathrm{H}$ Bottomley at Colgate/Palmolive and British Carborundum for providing the men who acted as controls. This study was supported by a grant from the North Western Regional Health Authority.

\section{References}

1 Keys A. Coronary heart disease-the global picture. Atherosclerosis. 1975;22:149-92.

2 Havel RJ, Goldstein JL, Brown MS. Lipoproteins and lipid transport. In: Bondy PK, Rosenberg LE, eds. Metabolic control and disease. 8th ed. Philadelphia: WB Saunders, 1980:393-494.

3 Kannel WB, Castelli WP, Gordon T, McNamara PM. Serum cholesterol, lipoproteins and the risk of coronary heart disease. Ann Intern Med 1971;74:1-12.

4 Kannel WB, Dawber TR, Friedman GD, Glennon WE, McNamara PM. Risk factors in coronary heart disease. An evaluation of several serum lipids as predictors of coronary heart disease. The Framingham 
study. Ann Intern Med 1964;61:888-99.

5 Dawber TR. The Framingham Study: the epidemiology of atherosclerotic disease. Cambridge, Massachusetts: Harvard University Press, 1980.

6 Blackburn $\mathrm{H}$, Jacobs $\mathrm{D}$. Coronary disease risk factors. In: Schettler FG, Gotto AM, Middlehoff G, Habenicht AJR, Juretka KR, eds. Atherosclerosis VI: Proceedings of the sixth international symposium on atherosclerosis. Berlin: Springer Verlag 1983:733-44.

7 Hulley SB, Rosenman RH, Bawol RD, Brand RJ. Epidemiology as a guide to clinical decisions. The association between triglyceride and coronary heart disease. $N$ Engl f Med 1980;302:1383-9.

8 Wilson PW, Garrison RJ, Castelli WP, Feinleib M, McNamara PM, Kannel WB. Prevalence of coronary heart disease in the Framingham offspring study: role of lipoprotein cholesterols. Am $\mathcal{F}$ Cardiol 1980;46: 649-54.

9 Rose G. Strategy of prevention: lessons from cardiovascular disease. $\mathrm{Br} \mathrm{Med} \mathcal{F} 1981$;282:1847-51.

10 Report of a WHO Expert Committee. Prevention of Coronary Heart Disease. WHO Tech Rep Ser 1982; No. 678.

11 Lowering Blood Cholesterol to Prevent Heart Disease. National Institute of Health Consensus Development Conference Statement 1985; 5: No. 7.

12 Gofman JW, DeLalla O, Glazier F, et al. The serum lipoprotein system in health, metabolic disease, atherosclerosis and coronary heart disease. Plasma 1954;2:413-84.

13 Miller NE, Hammett F, Saltissi S, et al. Relation of angiographically defined coronary artery disease to plasma lipoprotein subfractions and apolipoproteins. Br Med f 1981;282:1741-4.

14 Thompson G. Apoproteins: determinants of lipoprotein metabolism and indices of coronary risk. $\mathrm{Br}$ Heart $\mathcal{F}$ 1984;51:585-8.

15 Maciejko JJ, Holmes DR, Kottke BA, Zinsmeister AR, Dinh D, Mao SJT. Apolipoprotein AI as a marker of angiographically assessed coronary-artery disease. N Engl f Med 1983;309:385-9.

16 Durrington PN, Bolton CH, Hartog M. Serum and lipoprotein apolipoprotein B levels in normal subjects and patients with hyperlipoproteinaemia. Clin Chim Acta 1978;82:151-60.

17 Avogaro P, Bittolo Bon G, Cazzolato G, Quinci GB. Are apolipoproteins better discriminators than lipids for atherosclerosis? Lancet 1979;i:901-3.

18 Sniderman A, Shapiro S, Marpole D, Skinner B, Teng B, Kwiterovich PO. Association of coronary atherosclerosis with hyperapobetalipoproteinaemia (increased protein but normal cholesterol levels in human plasma low density $(\beta)$ lipoproteins). Proc Natl Acad Sci USA 1980;77:604-8.

19 Moss AJ, De Camilla JJ, Davis HP, Bayer L. Clinical significance of ventricular ectopic beats in the early posthospital phase of myocardial infarction. $A m \mathcal{F}$ Cardiol 1977;39:635-40.

20 Rose GA, Blackburn H, Gillum RF, Prineas RJ. Cardiovascular survey methods. 2nd ed. Geneva: World Health Organisation, 1982.

21 Fredrickson DS, Morganroth J, Levy RI, Type III hyperlipoproteinaemia: an analysis of two contem- porary definitions. Ann Intern Med 1975;82:150-7.

22 Siegel S. Nonparametric statistics for the behavioural sciences. New York: McGraw-Hill, 1956.

23 Klecka WR. Discriminant analysis. In: Nie NH, Hull $\mathrm{CH}$, Jenkins JG, Steinbrenner K, Bent DH, eds. Statistical package for the social sciences. 2nd ed. New York: McGraw-Hill, 1975:434-67.

24 Havel RJ, Eder HA, Bragdon JH. The distribution and chemical composition of ultracentrifugally separated lipoproteins in human serum. $\mathcal{f}$ Clin Invest 1955;34:1345-53.

25 Burstein M, Scholnick HR, Morfin R. Rapid method for the isolation of lipoproteins from human serum by precipitation with polyanions. $\mathcal{F}$ Lipid 1970;11: 583-95.

26 Gidez LI, Miller GJ, Burstein M, Slagle S, Eder HA. Separation and quantitation of subclasses of human high density lipoproteins by a simple precipitation procedure. $\mathcal{F}$ Lipid Res 1982;23:1206-23.

27 Steele BW, Koehler DF, Azar MM, Blaszkowski TP, Kuba K, Dempsey ME. Enzymatic determinations of cholesterol in high-density-lipoprotein fractions prepared by a precipitation technique. Clin Chem 1976;22:98-101.

28 Friedewald WT, Levy RI, Fredrickson DS. Estimation of serum low density lipoprotein cholesterol concentration in plasma without use of the preparative ultracentrifuge. Clin Chem 1972;18:499-502.

29 Durrington PN, Whicher JT, Warren C, Bolton $\mathrm{CH}$, Hartog M. A comparison of methods for the immunoassay of apolipoprotein B in man. Clin Chim Acta 1976;71:95-108.

30 Miller JP, Mao JT, Patsch JR, Gotto AM. The measurement of apolipoprotein AI in human plasma by electroimmunoassay. $\mathcal{F}$ Lipid Res 1980;21:775-80.

31 Fredrickson DS. Plasma lipoproteins and apolipoproteins. The Harvey Lectures, Series 68, 1972-3. New York: Academic Press, 1974:185-237.

32 Steinberg D. The rediscovery of high density lipoprotein: a negative risk factor in atherosclerosis. Eur f Clin Invest 1978;8:107-10.

33 Sniderman AD, Wolfson C, Teng B, Franklin FA, Bachorik PS, Kwiterovich PO. Association of hyperapobetalipoproteinaemia with endogenous hypertriglyceridaemia and atherosclerosis. Ann Intern Med 1982;97:833-9.

34 Sniderman AD, Teng B, Genest J, Cianflone $K$, Wacholder S, Kwiterovich P. Familial aggregation and early expression of hyperapobetalipoproteinaemia. Am $\mathcal{f}$ Cardiol 1985;55:291-5.

35 Durrington PN, Bolton $\mathrm{CH}$, Hartog $\mathrm{M}$, Angelinetta $\mathrm{R}$, Emmett P, Furniss S. The effect of a low-cholesterol, high-polyunsaturate diet on serum lipid levels, apolipoprotein B levels and triglyceride fatty acid composition. Atherosclerosis 1977;27:465-75.

36 Vega GL, Groszek E, Wolf R, Grundy SM. Influence of polyunsaturated fats on composition of plasma lipoproteins and apolipoproteins. $\mathcal{f}$ Lipid Res 1982;23:811-22.

37 Law A, Wallis SE, Powell LM, et al. Common DNA polymorphism within coding sequence of apolipoprotein B gene associated with altered lipid levels. Lancet 1986;i:1301-3. 